\title{
Polysaccharide-based nanoparticles for co-loading mitoxantrone and verapamil to overcome multidrug resistance in breast tumor
}

This article was published in the following Dove Press journal:

International Journal of Nanomedicine

10 October 2017

Number of times this article has been viewed

Yurui Xu'

Sajid Asghar ${ }^{2}$

Shiya Gao'

Zhipeng Chen ${ }^{3}$

Lin Huang'

Lining Yin'

Qineng Ping'

Yanyu Xiao'

'Department of Pharmaceutics, State Key Laboratory of Natural Medicines, China Pharmaceutical University, Nanjing, People's Republic of China; ${ }^{2}$ Faculty of Pharmaceutical Sciences, Government College University Faisalabad, Faisalabad, Pakistan; ${ }^{3}$ Department of Pharmacy, Nanjing University of Chinese Medicine, Nanjing, People's Republic of China
Correspondence: Yanyu Xiao Department of Pharmaceutics, State Key Laboratory of Natural Medicines, China Pharmaceutical University, No 24 Tong Jia Xiang, Nanjing 210009, People's Republic of China

Tel/fax +86258327 1079

Email cpuyanyuxiao@I63.com
Abstract: The aim of this study was to evaluate the potential of polyelectrolyte complex nanoparticles (PENPs) based on hyaluronic acid/chitosan hydrochloride (HA/HCS) for co-loading mitoxantrone (MTO) and verapamil (VRP) to overcome multidrug resistance in breast tumors. PENPs co-loaded with MTO and VRP (MTO-VRP-PENPs) were affected by the method of preparation, molecular weight of HA, mass ratios and initial concentrations of $\mathrm{HA} / \mathrm{HCS}, \mathrm{pH}$, and drug quantities. Optimized MTO-VRP-PENPs were $209 \mathrm{~nm}$ in size with a zeta potential of approximately $-24 \mathrm{mV}$. Encapsulation efficiencies (\%) of MTO and VRP were $98.33 \% \pm 0.27 \%$ and $44.21 \% \pm 8.62 \%$, respectively. MTO and VRP were successfully encapsulated in PENPs in a molecular or amorphous state. MTO-VRP-PENPs showed significant cytotoxicity in MCF-7/ ADR cells in contrast to MTO-loaded PENPs (MTO-PENPs). The reversal index of MTOVRP-PENPs was 13.25 and 10.33 times greater than that of the free MTO and MTO-PENPs, respectively. In conclusion, MTO-VRP-PENPs may serve as a promising carrier to overcome tumor drug resistance.

Keywords: hyaluronic acid, chitosan hydrochloride, mitoxantrone hydrochloride, verapamil hydrochloride, co-delivery, multidrug resistance

\section{Introduction}

Breast cancer, the most common invasive malignancy in women worldwide, is the second leading cause of cancer-related death after lung cancer. Currently, the main treatment for breast cancer is surgical resection with the combination of chemotherapy and radiotherapy. Mitoxantrone (MTO), a cell cycle nonspecific anticancer drug, can kill cancer cells in any cell cycle by inhibiting DNA replication and transcription. It has been clinically approved in the treatment of breast cancer, acute leukemia, hepatocellular carcinoma, and malignant lymphoma. ${ }^{1}$

Despite significant progress in early diagnosis and treatment, inadequate selection of anticancer drugs and multidrug resistance (MDR) to conventional chemotherapeutics continuously pose a tremendous challenge to effective breast cancer therapy. ${ }^{2}$ Particularly, drug resistance is a major obstacle in the treatment of breast cancer and may potentially lead to tumor relapse and the failure of therapy. ${ }^{3}$ In physiological conditions, $\mathrm{P}$-glycoprotein $(\mathrm{P}-\mathrm{gp})$ is mainly responsible for the transport of toxic chemicals out of the cell for its protection. While, in pathological conditions, P-gp is overexpressed in tumor cells and takes part in MDR. ${ }^{4}$ Because of the intimate relationship with MDR, P-gp has been widely studied as an important target for MDR reversal in recent years. Verapamil (VRP), a calcium antagonist, was reported to reverse MDR 
by Tsuruo et al. ${ }^{5}$ The MDR reversal mechanism was later demonstrated to involve both substrate competitive inhibition and gene regulation in the gene transcription process. ${ }^{6}$ In addition, VRP has also been reported to inhibit the activation of Scr kinase family to suppress tumor growth. ${ }^{7}$ However, P-gp not only exists in tumor tissues but also is widely distributed in the kidney, liver, adrenal glands, blood-brain barrier, and gastrointestinal tract, leading to unpredictable pharmacokinetic changes and adverse reactions.

There is growing interest in developing multi-agent co-delivery nanocarriers that can simultaneously incorporate and deliver multiple types of therapeutic drugs to disease sites in a targeted and controlled manner for combined therapy. These co-delivery nanocarriers may potentially allow synergetic effects of different therapeutic approaches to eventually improve overall treatment outcomes. Therefore, nanocarriers co-loaded with MTO and VRP could reverse MDR and reduce side effects. Polyelectrolyte complex nanoparticles (PENPs) are formed when two oppositely charged polyelectrolytes interact via electrostatic attraction and desolvation. PENPs have demonstrated great potential in biomedical and nano-biotechnological applications, including controlled drug release, good biocompatibility, and gene transfection. ${ }^{8}$ In this study, chitosan hydrochloride (HCS) was chosen as the cationic material owing to the abundance of positively charged terminal amine groups and better water solubility than chitosan (CS). Hyaluronic acid (HA) was chosen as the polyanion due to its negative charge in neutral and alkaline environments and tumor-targeting property through specific binding to the CD44 molecule, an integral membrane glycoprotein overexpressed on the surface of various tumor cells. $^{9-12}$

In the current study, PENPs were prepared using HCS and HA to simultaneously encapsulate positively charged MTO and neutral VRP (Figure 1) to enhance the selectivity of MTO and reverse the MDR of cancer cells. Key properties such as particle size, zeta potential, morphology, and encapsulation efficiency (EE\%) and drug loading (DL\%) of MTO and VRP were characterized. In vitro drug release was studied to explore the drug release pattern. Using doxorubicin hydrochloride (DOX) hydrochloride as a fluorescence probe, the cellular uptake of PENPs in both human breast cancer cell line MCF-7 and its adriamycin-resistant strain (MCF-7/ADR cell line) was investigated to explore the tumor-targeting and MDR suppression efficiency of the preparations. Cell retention rate $(\mathrm{RR})$ of the preparations in MCF-7/ADR cell line was calculated to evaluate the MDR reversal effect of the preparation. Furthermore, the exact location of the

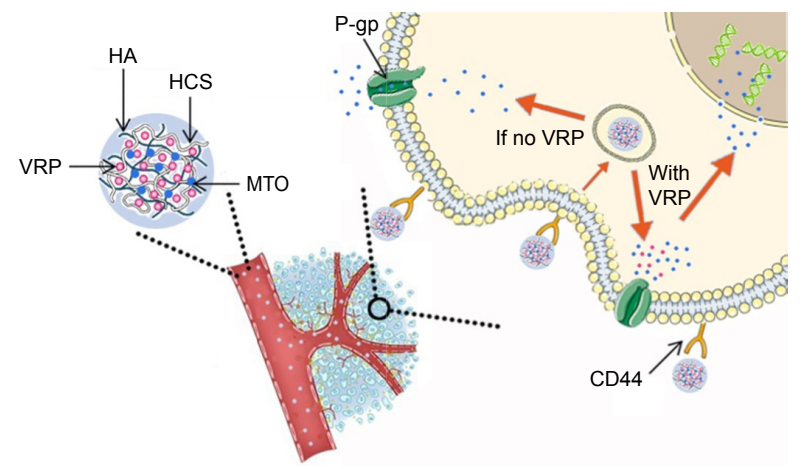

Figure I Schematic illustration of polysaccharide-based nanoparticles for co-loading MTO and VRP to overcome MDR in breast tumor.

Note: The formation of nanoparticles between negatively charged $\mathrm{HA}$ and positively charged HCS is shown.

Abbreviations: HA, hyaluronic acid; HCS, chitosan hydrochloride; MDR, multidrug resistance; MTO, mitoxantrone; VRP, verapamil.

preparation in cancer cells after being taken in was inspected by means of confocal laser scanning microscopy (CLSM).

\section{Materials and methods}

MTO (purity, 98\%), VRP (purity, 98\%), and DOX (purity, 98\%) were purchased from Sunnyhope Pharmaceutical Co., Ltd. (Sichuan, China), Huamaike Biotechnology Co., Ltd. (Beijing, China), and Aladdin Reagent Co., Ltd. (Shanghai, China), respectively. HCS (molecular weight [MW] $=100 \mathrm{kDa}$ determined by viscometry; degree of deacetylation $86 \%$ determined by ${ }^{1} \mathrm{H}$-nuclear magnetic resonance [NMR] spectroscopy) was purchased from Golden-Shell Biochemical Co., Ltd. (Zhejiang, China). HA (MW =10 kDa, 50 kDa, 120 kDa, and $500 \mathrm{kDa}$, determined by viscometry) was purchased from C.P. Freda Pharmaceutical Co., Ltd. (Shandong, China). The 3(4,5-dimethylthiazol-2-yl)-2,5-diphenyltetrazolium bromide (MTT) was purchased from Sigma-Aldrich Co. (St Louis, MO, USA). All other chemicals and reagents were of analytical grade and used without further purification.

\section{Preparation of PENPs co-loaded with MTO and VRP (MTO-VRP-PENPs) and MTO-loaded PENPs (MTO-PENPs)}

Different PENPs were prepared according to our previous work with slight modifications. ${ }^{13}$ In brief, $2 \mathrm{mg} / \mathrm{mL}$ solutions of HA and HCS were prepared in deionized water and filtered through $0.45 \mu \mathrm{m}$ microporous membranes. Blank PENPs were prepared by simply mixing the abovementioned solutions with a $6: 1$ volume ratio of HA:HCS. The mixture was kept stirring (400 rpm) for $2 \mathrm{~h}$ followed by filtration through a $0.45 \mu \mathrm{m}$ filter. To prepare MTO-VRPPENPs, MTO was added to the HA solution to obtain the 
concentration of $0.3 \mathrm{mg} / \mathrm{mL}$ of MTO (MTO-HA solution), and $\mathrm{pH}$ of the solution was adjusted to 4.0; VRP was added to the HCS solution to attain the concentration of $2 \mathrm{mg} / \mathrm{mL}$ of VRP (VRP-HCS solution). MTO-HA solution was added dropwise into the VRP-HCS solution under magnetic stirring (400 rpm) at $25^{\circ} \mathrm{C}$, and the resultant opalescent preparation was further stirred for $2 \mathrm{~h}$ to form MTO-VRP-PENPs. MTO-PENPs were prepared using the same procedure but without the addition of VRP.

Changes in the properties of blank PENPs were monitored for the changes in initial concentrations of HA and HCS solutions, MW of HA, and mass ratio of HA to HCS. The order of drug addition was also investigated in the formation of drug-loaded PENPs: if MTO or VRP was dissolved in HA solution and then mixed with HCS solution to obtain MTO loaded PENPs or VRP loaded PENPs (HMC-PENPs/ HVC-PENPs); CMH-PENPs/CVH-PENPs if MTO or VRP was dissolved in HCS solution and then mixed with HA solution; if MTO or VRP were added into blank PENPs to obtain MTO-loaded PENPs or VRP-loaded PENPs (CHMPENPs/CHV-PENPs). In addition, drug concentration, $\mathrm{pH}$, and mixing time were also investigated.

\section{Characterization of MTO-VRP-PENPs and MTO-PENPs}

The particle size, polydispersity index (PI), and zeta potential of different PENPs were analyzed by Zetasizer 3000HS (Malvern Instruments, Malvern, UK). MTO-VRP-PENPs' morphological observation was performed by transmission electron microscopy (TEM; H-7000; Hitachi Ltd., Tokyo, Japan). EE\% and DL\% were determined by the ultrafiltration method. In brief, $1 \mathrm{~mL}$ of MTO-VRP-PENPs or MTO-PENPs was transferred to an ultrafiltration centrifuge tube (MW cutoff [MWCO] of $100 \mathrm{kDa}$ ) and centrifuged for $30 \mathrm{~min}$ at $10,000 \mathrm{rpm}$. Approximately $100 \mu \mathrm{L}$ of the filtrate dissolved in $10 \mathrm{~mL}$ of mobile phase was analyzed by Agilent 1100 series high-performance liquid chromatography (HPLC) system (Agilent Technologies, Palo Alto, CA, USA) for measuring MTO and VRP concentrations. In addition, $100 \mu \mathrm{L}$ of PENPs dissolved in $10 \mathrm{~mL}$ of mobile phase was sonicated for $5 \mathrm{~min}$ followed by centrifugation for $10 \mathrm{~min}$ at $12,000 \mathrm{rpm}$. The supernatant was analyzed by HPLC for MTO and VRP. The stationary phase, $\mu$ Bondapak $\mathrm{C}_{18}$ column $(150 \times 4.6 \mathrm{~mm}$, $5 \mu \mathrm{m})$, was kept at $40^{\circ} \mathrm{C}$. The mobile phase for MTO was a 48:52 v/v mixture of methanol:0.2 mol/L ammonium acetate aqueous solution ( $\mathrm{pH}$ adjusted to 2 by $\mathrm{H}_{3} \mathrm{PO}_{4}$ ), and effluent was monitored at $241 \mathrm{~nm}$. The mobile phase of VRP was a 55:45:1 v/v mixture of acetic acid/sodium acetate buffer solution (1.36 g sodium acetate and $33 \mathrm{~mL}$ glacial acetic acid and volume made up to 1,000 $\mathrm{mL}$ ):methanol:triethylamine , and effluent was monitored at $278 \mathrm{~nm}$. The flow rate was set at $1.0 \mathrm{~mL} / \mathrm{min}$, and the injection volume was $20 \mu \mathrm{L}$. The $\mathrm{EE} \%$ and DL\% were calculated as follows:

$$
\mathrm{EE} \%=\frac{\mathrm{C}_{2} \times \mathrm{V}_{2}-\mathrm{C}_{1} \times \mathrm{V}_{1}}{\mathrm{C}_{2} \times \mathrm{V}_{2}} \times 100
$$

where $\mathrm{C}_{1}$ and $\mathrm{V}_{1}$ are the concentrations of the drug and the volume in the filtration tube after ultrafiltration, respectively, and $\mathrm{C}_{2}$ and $\mathrm{V}_{2}$ are the concentrations of the drug and the preparation volume before ultrafiltration, respectively.

$$
\mathrm{DL} \%=\frac{\mathrm{W}_{\mathrm{e}}}{\mathrm{W}_{\mathrm{e}}-\mathrm{W}_{\mathrm{f}}} \times 100
$$

where $\mathrm{W}_{\mathrm{e}}$ is the amount of the drug in PENPs, and $\mathrm{W}_{\mathrm{f}}$ is the amount of the feeding materials.

\section{Differential scanning calorimetry (DSC) analysis}

The thermal properties of MTO and VRP in the finalized formulation of MTO-VRP-PENPs were assessed using a Thermal Analyzer-60 WS, DSC-60 (Shimadzu, Kyoto, Japan). DSC patterns of MTO, VRP, blank PENPs, the physical mixture of VRP, MTO, and blank PENPs, and MTO-VRP-PENPs were tested in $20 \mathrm{~mL} / \mathrm{min} \mathrm{N}_{2}$ and at $10 \mathrm{~K} / \mathrm{min}$ heating rate.

\section{In vitro release study}

The in vitro release behavior of MTO-VRP-PENPs was carried out in $5 \%(\mathrm{w} / \mathrm{v})$ glucose solution $(\mathrm{pH} 7.4)$ using a dialysis method as reported previously. ${ }^{13}$ Briefly, $1 \mathrm{~mL}$ of MTO-VRP solution (the same quantities of MTO and VRP were dissolved in deionized water) and MTO-VRP-PENPs $\left(\mathrm{C}_{\mathrm{MTO}}=0.3 \mathrm{mg} / \mathrm{mL}, \mathrm{C}_{\mathrm{VRP}}=0.3 \mathrm{mg} / \mathrm{mL}\right)$ were transferred into dialysis bags (MWCO of $8-12 \mathrm{kDa}$ ) with both terminals clamped. The dialysis bags were immediately immersed into $50 \mathrm{~mL}$ of glucose solution under magnetic stirring in a water bath $\left(250 \mathrm{rpm}, 37^{\circ} \mathrm{C}\right)$. At specific intervals, $1 \mathrm{~mL}$ of the medium was withdrawn and replaced with $1 \mathrm{~mL}$ of fresh release medium maintained at $37^{\circ} \mathrm{C}$. The withdrawn samples were analyzed for measuring MTO and VRP concentrations by the HPLC system, as described earlier. The in vitro release assay was performed in triplicate. 


\section{Cell culture}

MCF-7 (a human breast adenocarcinoma cell line) and MCF-7/ADR (a human breast carcinoma cell line that has been made resistant by DOX and expresses a high level of P-gp) were both obtained from the cell bank of Chinese Academy of Sciences (Shanghai, China). MCF-7 cells were cultured in DMEM/high glucose medium (Thermo Fisher Scientific, Waltham, MA, USA) supplemented with $10 \%$ fetal calf serum (Thermo Fisher Scientific) and $1 \% 100 \mu \mathrm{g} / \mathrm{mL}$ penicillin-100 U/mL streptomycin (Thermo Fisher Scientific); MCF-7/ADR cells were cultured in RPMI 1640 medium (HyClone) supplemented with $15 \%$ fetal calf serum and $1 \% 100 \mu \mathrm{g} / \mathrm{mL}$ penicillin-100 $\mathrm{U} / \mathrm{mL}$ streptomycin. Both cell lines were cultured at $37^{\circ} \mathrm{C}$ in $5 \% \mathrm{CO}_{2}$ atmosphere.

\section{Cytotoxicity study}

MCF-7 cells and MCF-7/ADR cells were plated at a density of $5 \times 10^{3}$ cells/well in 96-well plates and incubated at $37^{\circ} \mathrm{C}$ under a humidified atmosphere with $5 \% \mathrm{CO}_{2}$ for $24 \mathrm{~h}$. Subsequently, the cells were treated with MTO solution, MTO-PENPs, and MTO-VRP-PENPs with increasing doses (total amount of MTO in PENPs): 0.05, 0.1, 0.5, 1, 5, 10, and $20 \mu \mathrm{g} / \mathrm{mL}$ for $24 \mathrm{~h}$. Cytotoxicity was carried out by MTT assay in both MCF-7 and MCF-7/ADR cell lines. The plates were incubated for an additional $4 \mathrm{~h}$. The culture medium was removed by aspiration. Thereafter, $150 \mu \mathrm{L}$ of dimethyl sulfoxide (DMSO) was added to each well to dissolve the formazan crystals while slightly stirring the cells using an automated shaker. The absorbance of samples in $570 \mathrm{~nm}$ $\left(\mathrm{A}_{570 \mathrm{~nm}}\right)$ was detected by enzyme-linked immunosorbent assay (ELISA; Thermo Electron Corporation, Beverly, MA, USA). The study was carried out six times. The ratio of the $A_{570 \mathrm{~nm}}$ of the preparations to that of the untreated cells as a percentage was used to express the cytotoxicity $\left(\mathrm{IC}_{50}\right)$.

\section{Cellular uptake studies}

DOX was selected as a fluorescent probe to study the uptake of cells through flow cytometry. Both DOX and MTO are non-cell cycle-specific anticancer drugs and the MDR mechanism of DOX is similar to MTO, mainly due to the efflux by P-gp, whereas DOX has a strong fluorescence, which is conducive to flow cytometry. ${ }^{14}$ PENPs co-loaded with DOX and VRP (DOX-VRP-PENPs) and DOX-PENPs were prepared using the same method as MTO-VRP-PENPs, and MTO-PENPs except replacing MTO with DOX.

MCF-7 and MCF-7/ADR cells were seeded in 24-well plates (Costar, Washington, DC, USA) with $5 \times 10^{5}$ cells/well density. After $24 \mathrm{~h}$ of cell culturing, the medium was replaced with DOX solution, DOX-PENPs, and DOX-VRP-PENPs to evaluate the effect of concentration $(0.05-20 \mu \mathrm{g} / \mathrm{mL}$ of DOX equivalent for $4 \mathrm{~h}$ ) and incubation time (1, 2, 4, 6, and $8 \mathrm{~h}$ at $10 \mu \mathrm{g} / \mathrm{mL}$ of DOX). The medium was then removed, and the cells were washed with ice-cold PBS three times followed by trypsinization. The cells were centrifuged at $1,000 \mathrm{rpm}$ for $3 \mathrm{~min}$ and analyzed by flow cytometer (BD Biosciences, San Jose, CA, USA). Both investigations were carried out in triplicate.

\section{Cell RR studies}

MCF-7/ADR cells were seeded in 24-well plates with $5 \times 10^{5}$ cells/well density. After $24 \mathrm{~h}$ of cell culturing, the media were replaced by DOX solution, DOX-PENPs, and DOX-VRP-PENPs (dissolved in RPMI 1640 cell culture medium without serum, $\mathrm{C}_{\mathrm{DOX}}=10 \mu \mathrm{g} / \mathrm{mL}$ ) and incubated for another $2 \mathrm{~h}$ at $37^{\circ} \mathrm{C}$. The cells were then washed with icecold PBS three times and re-cultured for $0,0.5,1,2$, and $4 \mathrm{~h}$ with RPMI 1640 cell culture medium (free of serum) before trypsinization for flow cytometry analysis. The cell RR was defined as the percentage of residual fluorescence intensity:

$$
\mathrm{RR} \%=\frac{\mathrm{F}_{\mathrm{s}}}{\mathrm{F}_{0}} \times 100 \%
$$

where $\mathrm{F}_{\mathrm{s}}$ is the fluorescence intensity of cells re-cultured for a specific period, and $\mathrm{F}_{0}$ is the fluorescence intensity of cells re-cultured for $0 \mathrm{~h}$.

In addition, the reversal index was defined as the ratio of $\mathrm{IC}_{50}$ of solution to the $\mathrm{IC}_{50}$ of formulations. ${ }^{15}$

\section{Intracellular trafficking ${ }^{16}$}

MCF-7/ADR cells were seeded in confocal dishes with $5 \times 10^{5}$ cells/well density and cultured at $37^{\circ} \mathrm{C}$ for $24 \mathrm{~h}$. The culture was then replaced by $400 \mu \mathrm{L}$ of DOX-VRP-PENPs (diluted by RPMI 1640 cell culture medium without serum) and incubated for $4 \mathrm{~h}$. The cells were washed thrice with icecold PBS, and Hoechst 33342 was used to dye the nucleus for $30 \mathrm{~min}$. After, cells were washed thrice by PBS, and $0.5 \mathrm{~mL}$ paraformaldehyde $(3.7 \% \mathrm{w} / \mathrm{v})$ was added for $15 \mathrm{~min}$ to fix the cells. Then, cells was washed thrice by PBS, and the samples were analyzed by CLSM (Leica Microsystems, Wetzlar, Germany).

\section{Statistical analyses}

One-way analysis of variance (ANOVA) was performed on all experimental data, and the means were compared using Student's $t$-test at the 5\% level with SPSS 11.0 software 
(SPSS Inc., Chicago, IL, USA). Differences were considered to be significant at $P<0.05$.

\section{Results and discussion Preparation of HA-HCS PENPs}

With the application of nanotechnology in drug delivery systems, numerous strategies are being developed to overcome MDR. Previous studies have shown the difficulties associated with the ordinary nano-drug delivery systems to achieve effective intracellular concentration due to smaller amounts of cellular uptake, slower intracellular release rate, and easy drug efflux. ${ }^{17}$ Therefore, to solve the problem of the common nanocarriers in overcoming MDR, a plethora of efforts to endow the nanocarriers with more functions is under investigation, and co-loading of P-gp inhibitors is one of the important strategies. Currently, there are reports of VRP and DOX co-loading in uniform mesoporous carbon spheres, liposomes, and bovine serum albumin nanoparticles. ${ }^{18-20}$ There are also a few reports about VRP-loaded polysaccharide or polyelectrolyte complexes; ${ }^{21}$ however, there are few reports about the co-loading of MTO and VRP in polyelectrolyte nanoparticles. ${ }^{22}$ Some pharmacological studies have showed that co-administration of MTO and VRP could enhance the efficacy of MTO..$^{23,24}$ Polyelectrolyte nanoparticles are usually used as the hydrophilic drug carrier; in this study, interaction of small molecule drugs with biocompatible materials was used to achieve drug loading, and a double drug carrier system with high drug loading and stability was obtained after comprehensive formulation investigation.

The formation of PENPs is driven by a variety of forces mainly through three steps: first, the mixing process involves the formation of an unstable complex of polyelectrolytes via electrostatic bonding. Second, the intracomplex formation process depends on the formation of new chemical bonds and the deformation of polymer chains inside the complex. Third, the intercomplex aggregation is governed by intermolecular forces. This finally leads to the formation of PENPs by desolvation. ${ }^{25}$

The polyelectrolyte composite system according to the macro-state can be divided into: 1) soluble complexes; 2) phase separation boundary colloid system; 3 ) supernatant and poly-salt precipitation system; 4) polyanions and polycationic concentrated solution of a macro-homogeneous system. No matter what the chemical structure of two polyelectrolytes, the abovementioned four conditions can be changed by changing the reaction conditions, such as the initial concentration, proportion, $\mathrm{pH}$, or ionic strength to achieve mutual conversion. ${ }^{26}$

\section{Effect of the MW of HA}

The MW of polyelectrolytes is one of the important factors that affect the properties of PENPs. ${ }^{27-29}$ Figure 2 shows the size and zeta potential of the blank PENPs prepared with different MWs of HA $(2 \mathrm{mg} / \mathrm{mL})$ and HCS solutions $(2 \mathrm{mg} / \mathrm{mL}$ ) at $400 \mathrm{rpm}$ stirring for $2 \mathrm{~h}$. PENPs prepared with $10 \mathrm{kDa}$ HA (Figure 2A) showed little change in size with changes in HCS and HA ratio (300-320 nm). PENPs prepared with $50 \mathrm{kDa}$ HA were in the range of $200-300 \mathrm{~nm}$ (Figure 2B). At a 2:1 ratio of HCS:HA, slightly bigger PENPs of $120 \mathrm{kDa}$ HA were obtained (418.8 nm), but increase in HA content initially decreased the size to $209 \mathrm{~nm}$ (HCS:HA =1:2) which increased to $279 \mathrm{~nm}$ on further increase in HA (HCS:HA =1:6; Figure 2C). Except for the 1:1 ratio of HCS:HA ( $>300 \mathrm{~nm}$ ), $500 \mathrm{kDa}$ HA PENPs were too large and size exceeded $500 \mathrm{~nm}$ (Figure 2D).

Decrease in HCS ratio from 2:1 to 1:2 markedly decreased the zeta potential of the blank PENPs from positive to negative, but the trend became more stable with further decrease in HCS. This indicates neutralization of the positive charge of HCS induced by increasing chains of HA. However, excessive increase in HA (the ratio of HA:HCS >3:1) allowed a majority of the $-\mathrm{NH}_{2}$ on the HCS to be occupied by the carboxyl of HA; thus, the excess carboxyl groups of HA remained exposed to the outside of the PENPs with a stable negative surface charge. ${ }^{27-29}$ Particle size of PENPs prepared by $50 \mathrm{kDa}$ HA was under $300 \mathrm{~nm}$ for all the HCS:HA volume ratios, so $50 \mathrm{kDa} \mathrm{HA}$ was chosen for subsequent experiments.

\section{Effect of the initial concentrations of HA and HCS solutions}

When the volume ratio of HCS to $50 \mathrm{kDa}$ HA was fixed at $1: 6$, the effect of the initial concentrations of HA and HCS on particle size of blank PENPs was investigated.

We can infer from Table 1 that the size of blank PENPs was mainly related to the concentration of $50 \mathrm{kDa} H A$. Zeta potential did not change significantly (around $-27 \mathrm{mV}$ ), by virtue of a greater proportion of HA than that of HCS in the PENPs. Large-sized particles were obtained for $50 \mathrm{kDa} H A$ solutions with strength greater than $2 \mathrm{mg} / \mathrm{mL}$. In addition, when the concentration of $50 \mathrm{kDa} H A$ solution was less than $2 \mathrm{mg} / \mathrm{mL}$, the system began to precipitate with the increase in HCS concentration. Our results are in good agreement with the findings of Buchhammer et al, ${ }^{30}$ that above a certain critical concentration PENPs become unstable and form insoluble precipitates. So, the concentrations of $2 \mathrm{mg} / \mathrm{mL}$ HA and HCS were selected for further studies. 
A
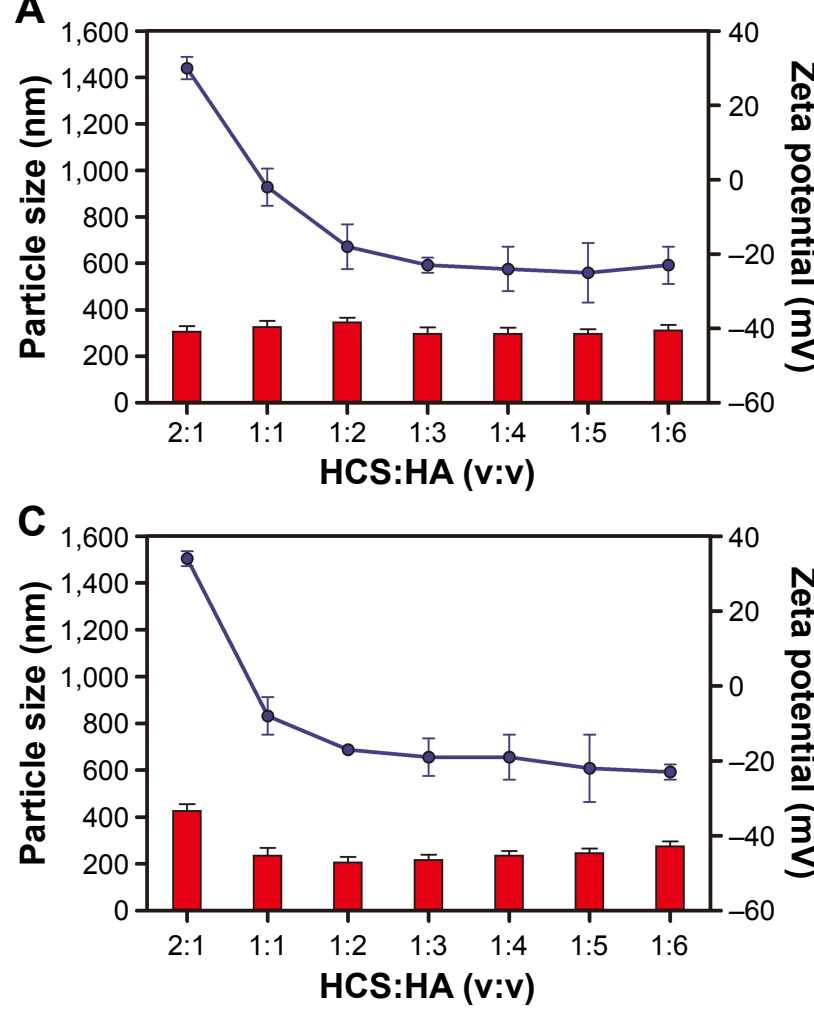

B

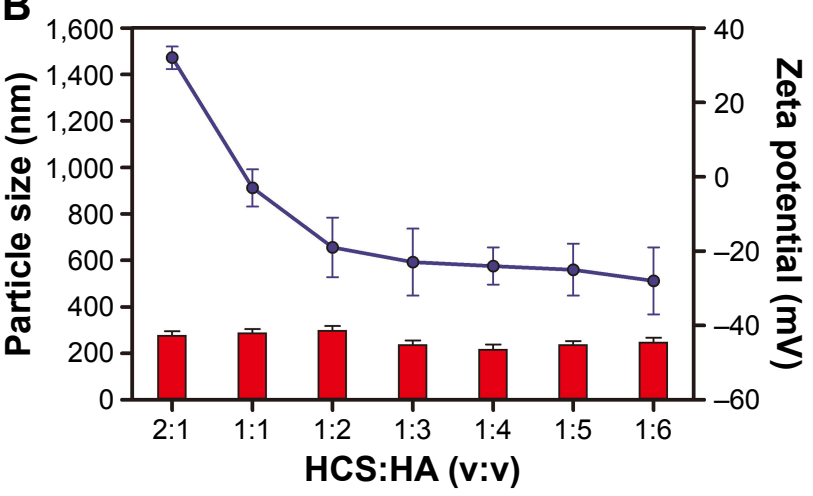

D

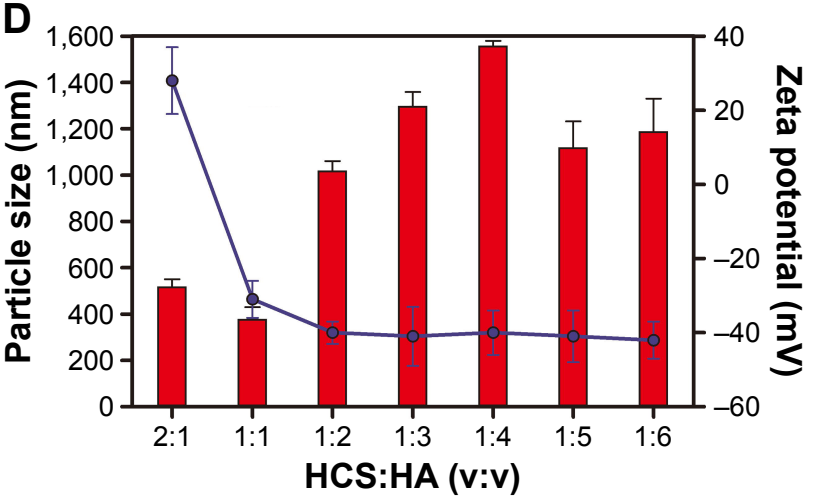

Particle size $\rightarrow-$ Zeta potential

Figure 2 Particle size and zeta potential of blank PENPs prepared by different mass ratios of $\mathrm{HCS}(2 \mathrm{mg} / \mathrm{mL}) \mathrm{and} \mathrm{HA}(2 \mathrm{mg} / \mathrm{mL})$.

Note: (A-D) MW of HA: 10 kDa, 50 kDa, 120 kDa, and $500 \mathrm{kDa}$.

Abbreviations: HA, hyaluronic acid; HCS, chitosan hydrochloride; MW, molecular weight; PENPs, polyelectrolyte complex nanoparticles.

\section{Effect of drug loading order}

Tables 2 and 3 summarize the effect of the order of addition of drugs on the particle size, zeta potential, and EE\% of PENPs when the volume ratio of HCS $(2 \mathrm{mg} / \mathrm{mL})$ to HA $(2 \mathrm{mg} / \mathrm{mL}$ ) was fixed at $1: 6$, and the drug concentrations were $\mathrm{MTO}=0.3 \mathrm{mg} / \mathrm{mL}$ and $\mathrm{VRP}=2 \mathrm{mg} / \mathrm{mL}$.

It is obvious from Table 2 that HMC-PENPs possessed the smallest size $(203.8 \mathrm{~nm})$ and higher EE\% of MTO (98.58\%) than the other two kinds of PENPs. In the HMC-PENP preparation method, MTO molecules might get adsorbed to

Table I Effect of the initial concentrations of HCS and $50 \mathrm{kDa}$ $\mathrm{HA}$ on the particle size $(\mathrm{nm})$ of blank PENPs with the ratio of $\mathrm{HCS}$ and $50 \mathrm{kDa} \mathrm{HA}$ solution at I:6 (v/v) $(\bar{X} \pm \mathrm{SD}, \mathrm{n}=3)$

\begin{tabular}{lllll}
\hline HCS & \multicolumn{4}{l}{$\mathbf{5 0} \mathbf{k D a}$ HA concentration $\mathbf{( m g / m L})$} \\
\cline { 2 - 5 } $\begin{array}{l}\text { concentration } \\
\mathbf{m g} / \mathbf{m L})\end{array}$ & $\mathrm{I}$ & $\mathbf{3}$ & $\mathbf{4}$ \\
\hline $\mathrm{I}$ & $237.86 \pm 1.3$ & $410.89 \pm 0.9$ & $473.97 \pm 2.1$ & $536.66 \pm 2.6$ \\
2 & $257.95 \pm 3.2$ & $209.75 \pm 2.1$ & $309.76 \pm 5.4$ & $400.69 \pm 1.3$ \\
3 & Precipitation & $259.88 \pm 2.5$ & $244.48 \pm 13.6$ & $432.88 \pm 6.8$ \\
4 & Precipitation & Precipitation & $363.65 \pm 30.2$ & $461.22 \pm 10.0$ \\
\hline
\end{tabular}

Abbreviations: HA, hyaluronic acid; HCS, chitosan hydrochloride; PENPs, polyelectrolyte complex nanoparticles.
HA by virtue of electrovalent attraction through the electropositive imino group of MTO with the carboxyl group of HA. Particle size and zeta potential of VRP-loaded PENPs (Table 3) prepared by a different method were almost similar but with a maximum EE\% of only $44.62 \%$ for CVH-PENPs. VRP could not combine with the carrier material by ionic interaction because of its electrical neutrality. Encapsulation of VRP into the PENPs could be due to the Van der Waals' forces between the drug and the polymers. Peng et $\mathrm{a}^{31}$ prepared alginate/ calcium carbonate hybrid microparticles to co-deliver DOX

Table 2 Effect of the loading order of MTO on the characteristics of PENPs with the ratio of HCS and $50 \mathrm{kDa} H A$ solution at I:6 (v/v)

\begin{tabular}{llll}
\hline Preparation & CMH-PENPs & HMC-PENPs & CHM-PENPs \\
\hline Size $(\mathrm{nm})$ & $270.6 \pm 4.7$ & $203.8 \pm 12.1$ & $246.1 \pm 4.9$ \\
Zeta potential $(\mathrm{mV})$ & $-26.13 \pm 1.07$ & $-21.89 \pm 0.90$ & $-18.69 \pm 2.91$ \\
EE $(\%)$ of MTO & $88.44 \pm 1.35$ & $98.58 \pm 3.16$ & $91.48 \pm 1.76$ \\
\hline
\end{tabular}

Notes: The drug concentrations were: $M T O=0.3 \mathrm{mg} / \mathrm{mL}$ and VRP $=2 \mathrm{mg} / \mathrm{mL}$ $(\bar{X} \pm S D, n=3)$. MTO was dissolved in HCS solution and then mixed with HA solution to obtain MTO loaded PENPs (CMH-PENPs); MTO was dissolved in HA solution and then mixed with HCS solution to obtain MTO loaded PENPs (HMC-PENPs); MTO were added into blank PENPs to obtain MTO loaded PENPs (CHM-PENPs). Abbreviations: EE, encapsulation efficiency; HA, hyaluronic acid; HCS, chitosan hydrochloride; MTO, mitoxantrone; PENPs, polyelectrolyte complex nanoparticles; VRP, verapamil. 
Table 3 Effect of the loading order of VRP on the characteristics of PENPs with the ratio of HCS and $50 \mathrm{kDa} H A$ solutions at $1: 6(\mathrm{v} / \mathrm{v})$

\begin{tabular}{llll}
\hline Preparation & CVH-PENPs & HVC-PENPs & CHV-PENPs \\
\hline Size $(\mathrm{nm})$ & $224.1 \pm 5.0$ & $224.8 \pm 0.7$ & $243.1 \pm 6.5$ \\
Zeta potential $(\mathrm{mV})$ & $-25.52 \pm 0.37$ & $-26.69 \pm 1.5 \mathrm{I}$ & $-26.5 \mathrm{I} \pm \mathrm{I} .24$ \\
EE $(\%)$ of VRP & $44.62 \pm 3.44$ & $35.32 \pm 3.5 \mathrm{I}$ & $34.72 \pm 6.1 \mathrm{I}$
\end{tabular}

Notes: The drug concentrations were: $M T O=0.3 \mathrm{mg} / \mathrm{mL}$ and VRP $=2 \mathrm{mg} / \mathrm{mL}$ $(\bar{X} \pm S D, n=3)$. VRP was dissolved in HCS solution and then mixed with HA solution to obtain VRP loaded PENPs (CVH-PENPs); VRP was dissolved in HA solution and then mixed with HCS solution to obtain VRP loaded PENPs (HVC-PENPs); VRP were added into blank PENPs to obtain VRP loaded PENPs (CHV-PENPs).

Abbreviations: EE, encapsulation efficiency; HA, hyaluronic acid; HCS, chitosan hydrochloride; MTO, mitoxantrone; PENPs, polyelectrolyte complex nanoparticles; VRP, verapamil.

and VRP and obtained much lower EE\% of VRP (49.6\%) as compared to the positively charged DOX $(90.0 \%)$, which is consistent with our results. From the experimental results, the affinity of VRP with HCS was slightly higher than HA, so the preparation method of CVH-PENPs was chosen.

\section{Effect of the mass ratio of HCS and HA in MTO-VRP-PENPs}

The effect of HCS:HA ratio on the characteristics of MTO-VRP-PENPs, when the drug concentrations were $\mathrm{MTO}=0.3 \mathrm{mg} / \mathrm{mL}$ and $\mathrm{VRP}=2 \mathrm{mg} / \mathrm{mL}$, and $2 \mathrm{mg} / \mathrm{mL}$ of HA and HCS solutions were used, is given in Table 4.

A slight but gradual decrease in the particle size and potential of PENPs was observed for increasing proportion of HA. The EE\% of MTO remained more than $90 \%$ for all ratios, but the EE\% of VRP gradually increased. Higher levels of HA in the PENPs could have caused more tight wrapping of HCS resulting in decreased loss of the adsorbed drug and thus higher VRP encapsulation. So, HCS:HA ratio of 1:6 was chosen for further experiments.

\section{Screening drug concentrations}

When screening for the concentration of MTO, the VRP concentration was fixed at $2 \mathrm{mg} / \mathrm{mL}$, and when screening for

Table 4 Effect of HCS:HA ratio on the characteristics of MTO-VRP-PENPs $(\bar{X} \pm S D, n=3)$

\begin{tabular}{|c|c|c|c|c|}
\hline \multirow{2}{*}{$\begin{array}{l}\text { HCS:HA } \\
\text { ratio }\end{array}$} & \multirow{2}{*}{$\begin{array}{l}\text { Particle } \\
\text { size }(n m)\end{array}$} & \multirow{2}{*}{$\begin{array}{l}\text { Zeta potential } \\
(\mathrm{mV})\end{array}$} & \multicolumn{2}{|l|}{ EE\% } \\
\hline & & & МТO & VRP \\
\hline $\mathrm{I}: 2$ & Precipitation & - & - & - \\
\hline $1: 3$ & $279.2 \pm 12.6$ & $-19.09 \pm 2.45$ & $93.71 \pm 0.35$ & $31.81 \pm 1.04$ \\
\hline $\mathrm{I}: 4$ & $250.2 \pm 17.9$ & $-20.57 \pm 1.48$ & $93.12 \pm 1.89$ & $39.08 \pm 7.41$ \\
\hline $\mathrm{I}: 5$ & $235.9 \pm 8.1$ & $-21.74 \pm 3.26$ & $91.45 \pm 4.78$ & $40.49 \pm 9.37$ \\
\hline $\mathrm{I}: 6$ & $218.2 \pm 5.5$ & $-23.26 \pm 2.10$ & $94.89 \pm 2.01$ & $44.25 \pm 1.17$ \\
\hline
\end{tabular}

Table 5 Effect of MTO strength on the characteristics of MTOVRP-PENPs when the VRP concentration was fixed at $2 \mathrm{mg} / \mathrm{mL}$ $(\bar{X} \pm S D, n=3)$

\begin{tabular}{|c|c|c|c|c|}
\hline \multirow{2}{*}{$\begin{array}{l}\text { MTO } \\
\text { concentration } \\
(\mathrm{mg} / \mathrm{mL})\end{array}$} & \multirow{2}{*}{$\begin{array}{l}\text { Particle } \\
\text { size }(\mathrm{nm})\end{array}$} & \multirow{2}{*}{$\begin{array}{l}\text { Zeta } \\
\text { potential } \\
(\mathrm{mV})\end{array}$} & \multicolumn{2}{|l|}{ EE\% } \\
\hline & & & MTO & VRP \\
\hline 0.2 & $203.4 \pm 9.6$ & $-25.3 \mid \pm 3.82$ & $95.04 \pm 1.28$ & $43.78 \pm 5.21$ \\
\hline 0.3 & $211.3 \pm 9.0$ & $-23.40 \pm 0.58$ & $97.86 \pm 1.68$ & $44.4 I \pm 4.08$ \\
\hline 0.4 & $225.6 \pm 24.5$ & $-28.01 \pm 6.07$ & $90.02 \pm 2.51$ & $36.73 \pm 11.02$ \\
\hline 0.5 & Precipitation & - & - & - \\
\hline
\end{tabular}

Notes: -, no detection; MTO-VRP-PENPs, PENPs co-loaded with MTO and VRP. Abbreviations: EE, encapsulation efficiency; MTO, mitoxantrone; PENPs, polyelectrolyte complex nanoparticles; VRP, verapamil.

the VRP concentration, the MTO concentration was fixed at $0.3 \mathrm{mg} / \mathrm{mL}$, while other preparation conditions were kept constant as determined earlier. MTO-VRP-PENPs properties are given in Tables 5 and 6.

Precipitation of the preparation observed at higher level of MTO might be explained by increase in the $\mathrm{pH}$ of the medium due to its strong alkaline nature, leading to instability of the nanoparticles. Quantity of VRP also did not affect EE\% of MTO as the interaction between VRP and the carrier material was weaker. However, $3 \mathrm{mg} / \mathrm{mL}$ of VRP significantly lowered EE\% of MTO $(73.90 \% \pm 2.08 \%)$. Both MTO and VRP in the co-loaded PENP system were likely to occupy the hydrophilic sites due to their hydrophilic nature, so the EE\% of MTO reduced with the increase of VRP concentration, indicating interference caused by VRP with the encapsulation of MTO in the polyelectrolyte system, at higher concentrations during the loading process. Finally, $0.3 \mathrm{mg} / \mathrm{mL}$ MTO and $2 \mathrm{mg} / \mathrm{mL}$ VRP were chosen in the making of PENPs.

\section{Effect of the system pH}

In general, when PENPs are formed by strong electrolytes, the $\mathrm{pH}$ of the medium has little effect on the complexation process. If one component of the system is a weak electrolyte, the $\mathrm{pH}$ of the medium will affect the dissociation

Table 6 Effect of VRP concentration on the characteristics of MTO-VRP-PENPs when the MTO concentration was fixed at $0.3 \mathrm{mg} / \mathrm{mL}(\bar{X} \pm S D, \mathrm{n}=3)$

\begin{tabular}{|c|c|c|c|c|}
\hline \multirow{2}{*}{$\begin{array}{l}\text { VRP } \\
\text { concentration } \\
(\mathrm{mg} / \mathrm{mL})\end{array}$} & \multirow{2}{*}{$\begin{array}{l}\text { Particle } \\
\text { size }(\mathrm{nm})\end{array}$} & \multirow{2}{*}{$\begin{array}{l}\text { Zeta } \\
\text { potential } \\
(\mathrm{mV})\end{array}$} & \multicolumn{2}{|l|}{ EE\% } \\
\hline & & & МTO & VRP \\
\hline I & $201.0 \pm 7.3$ & $-29.78 \pm 1.95$ & $92.5 \mathrm{I} \pm 8.60$ & $49.39 \pm 10.9$ \\
\hline 1.5 & $207.6 \pm 3.9$ & $-27.55 \pm 3.54$ & $92.23 \pm 7.33$ & $46.01 \pm 10.7$ \\
\hline 2 & $203.3 \pm 8.7$ & $-27.36 \pm 2.03$ & $97.84 \pm 5.71$ & $46.5 \mathrm{I} \pm 6.27$ \\
\hline 3 & $208.7 \pm 10.4$ & $-28.90 \pm 2.23$ & $73.90 \pm 2.08$ & $43.31 \pm 9.56$ \\
\hline
\end{tabular}

Note: MTO-VRP-PENPs, PENPs co-loaded with MTO and VRP.

Abbreviations: EE, encapsulation efficiency; MTO, mitoxantrone; PENPs, polyelectrolyte complex nanoparticles; VRP, verapamil. 
Table 7 Effect of $\mathrm{pH}$ on the characteristics of MTO-VRP-PENPs $(\bar{X} \pm \mathrm{SD}, \mathrm{n}=3)$

\begin{tabular}{|c|c|c|c|c|}
\hline \multirow{2}{*}{$\begin{array}{l}\mathrm{pH} \\
\text { value }\end{array}$} & \multirow{2}{*}{$\begin{array}{l}\text { Particle } \\
\text { size }(\mathrm{nm})\end{array}$} & \multirow{2}{*}{$\begin{array}{l}\text { Zeta potential } \\
(\mathrm{mV})\end{array}$} & \multicolumn{2}{|l|}{ EE\% } \\
\hline & & & MTO & VRP \\
\hline 2.0 & Precipitation & - & - & - \\
\hline 4.0 & $209.2 \pm 6.4$ & $-24.28 \pm 1.85$ & $97.8 I \pm 6.45$ & $44.34 \pm 4.54$ \\
\hline 7.0 & $275.9 \pm 6.8$ & $-24.2 \mathrm{I} \pm 2.86$ & $78.89 \pm 0.97$ & $41.32 \pm 1.45$ \\
\hline 9.0 & $263.8 \pm 12.6$ & $-23.07 \pm 2.31$ & $88.77 \pm 8.46$ & $49.19 \pm 5.61$ \\
\hline 10.0 & Precipitation & - & - & - \\
\hline
\end{tabular}

Notes: -, no detection; MTO-VRP-PENPs, PENPs co-loaded with MTO and VRP. Abbreviations: EE, encapsulation efficiency; MTO, mitoxantrone; PENPs, polyelectrolyte complex nanoparticles; VRP, verapamil.

degree and effective charge density of weak polyelectrolyte ionic groups (such as $-\mathrm{COO}^{-}$in $\mathrm{HA}$ ), ${ }^{32}$ thereby affecting PENP formation. In addition, $\mathrm{pH}$ can affect the conformation and the chain rigidity of the polymer. ${ }^{33}$ Therefore, PENP formation can be affected by $\mathrm{pH}$ environment operating through the abovementioned factors, resulting in particle size and zeta potential variations.

In this study, the $\mathrm{pH}$ of the solution determines the degree of ionization of carboxylic acid groups of the HA (pKa 3.2) and amino groups of the HCS (pKa 6.5), which might affect the particle size, zeta potential, and drug loading of PENPs (pKa of MTO is 8.5$) \cdot{ }^{34}$ Table 7 presents results showing that particle size and zeta potential of PENPs and EE\% of both MTO and VRP changed by the addition of weak acid (acetic acid) or weak base (aqueous ammonia) in the MTO-HA solution. PENPs made at $\mathrm{pH} 4.0$ and $\mathrm{pH} 9.0$ had the maximum $\mathrm{EE} \%$ and $\mathrm{DL} \% \%$ of both MTO and VRP compared to those made at $\mathrm{pH} 7.0$ (Table 7), indicating that better interaction between the HA and MTO exists in the appropriate acid/alkali medium, making electrostatic adsorption more stable. Extreme $\mathrm{pH}$ conditions (2 and 10) did not favor the formation of PENPs. Formulations made at $\mathrm{pH} 4.0$ generated smaller size MTO-VRP-PENPs; therefore, $\mathrm{pH} 4.0$ was selected as the optimum medium $\mathrm{pH}$.

\section{Effect of the mixing time}

As summarized in Table 8, the EE\% and DL\% of MTO and VRP were at higher levels for a $2 \mathrm{~h}$ mixing time. Particle size and zeta potential did not vary significantly with the mixing time. However, longer mixing time caused significant decrease in the $\mathrm{EE} \%$ of both drugs. Because of prolonged stirring drug leakage might have occurred, as energy around the particles could have been intensified by the molecular motion leading to increased collision between the particles.

Table 9 summarizes the key features of the optimized MTO-VRP-PENPs and MTO-PENPs. Figure 3F showed that TEM image of MTO-VRP-PENPs was the quasi-spherical shape.

\section{DSC analysis}

Figure 3 shows the DSC thermograms of pure MTO, pure VRP, blank PENPs, physical mixture of MTO, VRP, and blank PENPs, and MTO-VRP-PENP powder. Pure MTO and VRP showed a sharp endothermal peak at $173.5^{\circ} \mathrm{C}$ and $141.6^{\circ} \mathrm{C}$, respectively, indicating the typical behavior of the drugs. ${ }^{35}$ The thermogram of the physical mixture of drugs and blank PENPs did not show peak of MTO but showed a low-intensity characteristic the peak of VRP. It showed that the negatively charged hydrophilic PENPs interacted with both hydrophilic drugs even in the physical mixing process. Positively charged hydrophilic MTO showed much better interaction with the carrier due to the electrostatic charges. This type of phenomenon has been observed for the solid dispersions prepared by physical mixing of hydrophilic carrier with the drugs. ${ }^{36}$ There was no significant difference in the diffraction pattern of blank PENPs and MTO-VRP-PENPs, indicating that the addition of MTO and VRP had not changed the nature of PENPs and the drugs were entrapped inside the PENPs in a molecular or amorphous state.

\section{In vitro release study}

The release studies showed rapid release of MTO (78.12\%) and VRP (87.36\%) from MTO-VRP solution within the first $2 \mathrm{~h}$ (Figure 4). MTO-VRP-PENPs released the MTO in a controlled fashion (only $38.61 \%$ up to $5 \mathrm{~h}$ and $60 \%$ until $24 \mathrm{~h}$ ), whereas the release of VRP from MTO-VRP-PENPs

Table 8 Effect of stirring time on the characteristics of MTO-VRP-PENPs $(\bar{X} \pm S D, n=3)$

\begin{tabular}{|c|c|c|c|c|c|c|}
\hline \multirow{2}{*}{$\begin{array}{l}\text { Stirring } \\
\text { time (h) }\end{array}$} & \multirow{2}{*}{$\begin{array}{l}\text { Particle } \\
\text { size }(\mathrm{nm})\end{array}$} & \multirow{2}{*}{$\begin{array}{l}\text { Zeta potential } \\
(\mathrm{mV})\end{array}$} & \multicolumn{2}{|l|}{ EE\% } & \multicolumn{2}{|l|}{ DL\% } \\
\hline & & & Мто & VRP & MTO & VRP \\
\hline 0.5 & $228.1 \pm 7.3$ & $-25.63 \pm 4.05$ & $86.42 \pm 14.06$ & $44.39 \pm 1.88$ & $6.52 \pm 1.06$ & $4.49 \pm 1.94$ \\
\hline I & $228.0 \pm 5.3$ & $-33.06 \pm 4.76$ & $87.22 \pm 8.33$ & $30.21 \pm 1.38$ & $6.56 \pm 0.74$ & $3.98 \pm 0.18$ \\
\hline 2 & $211.3 \pm 9.0$ & $-23.41 \pm 0.58$ & $94.84 \pm 1.68$ & $45.20 \pm 4.08$ & $8.12 \pm 0.46$ & $4.52 \pm 0.42$ \\
\hline 4 & $207.9 \pm 5.8$ & $-26.48 \pm 5.44$ & $71.39 \pm 14.81$ & $35.32 \pm 4.48$ & $3.78 \pm 1.56$ & $3.64 \pm 0.44$ \\
\hline 6 & $220.5 \pm 10.5$ & $-30.92 \pm 3.9 \mid$ & $74.62 \pm 11.40$ & $24.4 I \pm 3.2 I$ & $4.09 \pm 0.64$ & $2.64 \pm 0.36$ \\
\hline
\end{tabular}

Note: MTO-VRP-PENPs, PENPs co-loaded with MTO and VRP.

Abbreviations: DL, drug loading; EE, encapsulation efficiency; MTO, mitoxantrone; PENPs, polyelectrolyte complex nanoparticles; VRP, verapamil. 
Table 9 Characterization of optimized MTO-VRP-PENPs and MTO-PENPs $(\bar{X} \pm S D, n=3)$

\begin{tabular}{|c|c|c|c|c|c|c|c|}
\hline \multirow[t]{2}{*}{ Preparation } & \multirow{2}{*}{$\begin{array}{l}\text { Particle } \\
\text { size }(\mathrm{nm})\end{array}$} & \multirow[t]{2}{*}{$\mathbf{P I}$} & \multirow{2}{*}{$\begin{array}{l}\text { Zeta potential } \\
(\mathrm{mV})\end{array}$} & \multicolumn{2}{|l|}{ EE (\%) } & \multicolumn{2}{|c|}{ DL\% (wt\%) } \\
\hline & & & & MTO & VRP & MTO & VRP \\
\hline MTO-VRP-PENPs & $209.8 \pm \mid 4.1$ & $0.12 \pm 0.046$ & $-23.98 \pm 3.03$ & $98.33 \pm 0.27$ & $44.21 \pm 8.62$ & $8.21 \pm 0.25$ & $4.43 \pm 0.97$ \\
\hline MTO-PENPs & $200.4 \pm 9.4$ & $0.10 \pm 0.018$ & $-21.34 \pm 1.25$ & $99.47 \pm 0.13$ & - & $9.78 \pm 0.14$ & - \\
\hline
\end{tabular}

Notes: -, no detection; MTO-PENPs, MTO-loaded PENPs; MTO-VRP-PENPs, PENPs co-loaded with MTO and VRP.

Abbreviations: DL, drug loading; EE, encapsulation efficiency; MTO, mitoxantrone; PENPs, polyelectrolyte complex nanoparticles; PI, polydispersity index; VRP, verapamil.

was much quicker than that of MTO $(82.77 \%$ at $5 \mathrm{~h})$. Positively charged MTO would have been firmly combined with HA through electrostatic interactions, whereas weak intermolecular Van der Waal's forces might explain rapid expulsion of VRP (a neutral drug), which is consistent with the previous findings. ${ }^{37}$

\section{Cytotoxicity assays}

MTT assay was performed to evaluate the effect of blank PENPs on the cell viability of MCF-7 and MCF-7/ADR cells. Results showed that the cell viability of MCF-7 and

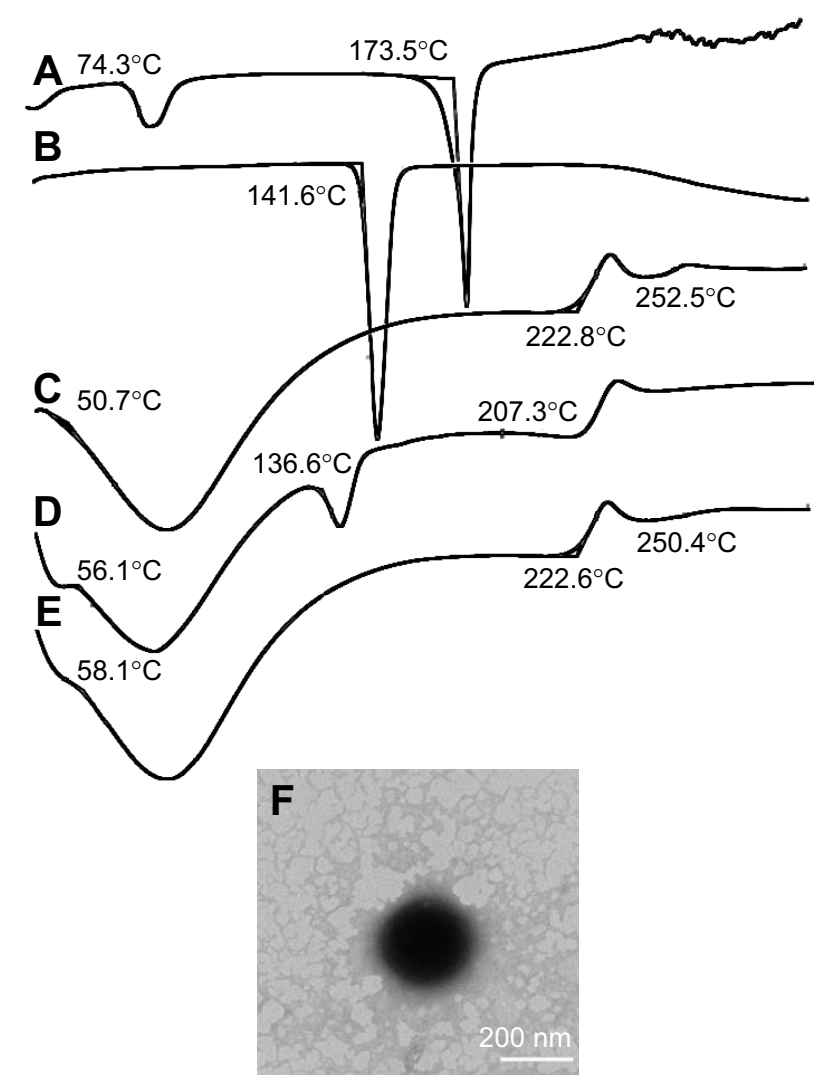

Figure 3 DSC images of MTO (A), VRP (B), blank PENPs (C), physical mixture of MTO, VRP, and blank PENPs (D), MTO-VRP-PENP powder (E); transmission electron micrograph $(\times 10,000)$ of MTO-VRP-PENPs $(\mathbf{F})$. MTO-VRP-PENPs, PENPs co-loaded with MTO and VRP.

Abbreviations: DSC, differential scanning calorimetry; MTO, mitoxantrone; PENPs, polyelectrolyte complex nanoparticles; VRP, verapamil.
MCF-7/ADR cells incubated with blank PENPs at tested concentrations ranging from 10 to $500 \mu \mathrm{g} / \mathrm{mL}$ for $24 \mathrm{~h}$ were all over $80 \%$ (data no shown), indicating that blank PENPs in the studied concentrations have no effect on cell viability of MCF-7 and MCF-7/ADR cells, suggesting blank PENPs might be good biocompatible carriers for drug delivery.

Figure $5 \mathrm{~A}$ and $\mathrm{B}$ indicates concentration-dependent inhibition of the growth of MCF-7 and MCF-7/ADR cells by three formulations. All preparations did not show cytotoxicity for MCF-7 and MCF-7/ADR cells when the concentration of MTO was below $0.1 \mu \mathrm{g} / \mathrm{mL}$. Cell survival rate of MCF-7/ ADR cells was reduced to $44.66 \%$ when the concentration of MTO was $5 \mu \mathrm{g} / \mathrm{mL}$ in the MTO-VRP-PENPs group, whereas the survival rate of MCF-7/ADR cells was $80.37 \%$ and $67.57 \%$ in the MTO solution and MTO-PENPs groups, respectively. The cytotoxicity of MTO-VRP-PENPs was significantly higher than the other two groups at the same concentrations; the MCF-7/ADR cell survival rate of MTO-VRP-PENPs, MTO-PENPs, and MTO solution was $18.26 \%, 55.28 \%$, and $61.67 \%$, respectively, for $20 \mu \mathrm{g} / \mathrm{mL}$ MTO. These results suggested that synergistic delivery of chemotherapy drugs by MTO-VRP-PENPs could achieve enhanced therapeutic efficacy.

MCF-7 cells were sensitive to free MTO solution ( $\mathrm{IC}_{50}$ of $2.40 \pm 0.53 \mu \mathrm{g} / \mathrm{mL}, \mathrm{n}=3$ ), while MCF-7/ADR cells were resistant to free MTO solution $\left(\mathrm{IC}_{50}\right.$ of $49.15 \pm 0.28 \mu \mathrm{g} / \mathrm{mL}$, $\mathrm{n}=3$ ). MTO-PENPs showed slightly better cytotoxicity than MTO solution for MCF-7 $\left(\mathrm{IC}_{50}\right.$ of $2.06 \pm 0.64 \mu \mathrm{g} / \mathrm{mL}, \mathrm{n}=3$ ) and MCF-7/ADR cells ( $\mathrm{IC}_{50}$ of $38.33 \pm 0.38 \mu \mathrm{g} / \mathrm{mL}, \mathrm{n}=3$ ). However, MTO-VRP-PENPs showed greater cytotoxicity in both MCF-7 cells ( $\mathrm{IC}_{50}$ of $1.19 \pm 0.48 \mu \mathrm{g} / \mathrm{mL}, \mathrm{n}=3$ ) and MCF-7/ADR cells ( $\mathrm{IC}_{50}$ of $3.71 \pm 0.15 \mu \mathrm{g} / \mathrm{mL}, \mathrm{n}=3$ ) in contrast to the MTO-PENPs and free MTO solution. VRP is a firstgeneration P-gp inhibitor shown to reverse drug resistance in P-gp overexpressing MDR tumor cells. ${ }^{38}$ Since the released VRP molecules from PENPs had the ability to competitively bind with the P-gp, ${ }^{39-41}$ the accumulation of released MTO molecules in MCF-7/ADR cells was significantly improved, leading to a much higher cytotoxicity of MTO-VRP-PENPs compared to the MTO-PENPs. A recently published study 
A

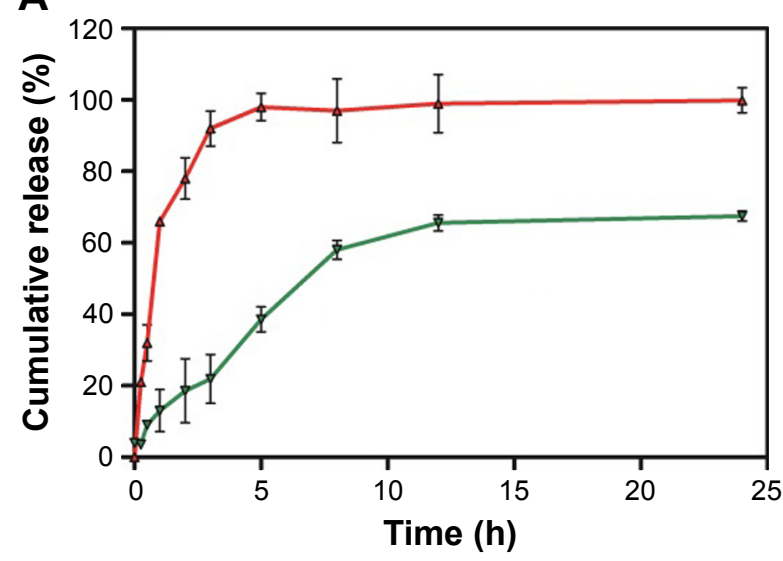

B

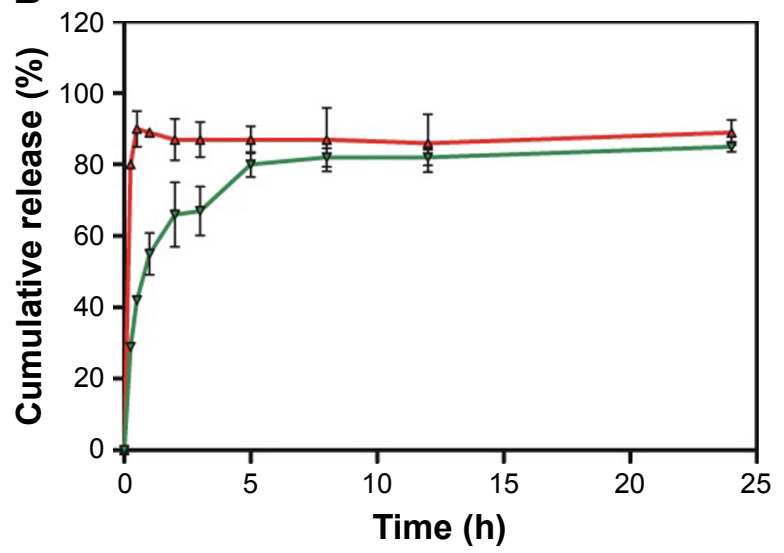

MTO-VRP solution $\rightarrow$ MTO-VRP-PENPs

Figure 4 In vitro cumulative release (\%) of MTO (A) and VRP (B) from MTO-VRP solution and MTO-VRP-PENPs in 5\% ( $w / v)$ glucose solution, respectively ( $\mathrm{n}=3$ ). Note: MTO-VRP-PENPs, PENPs co-loaded with MTO and VRP.

Abbreviations: MTO, mitoxantrone; PENPs, polyelectrolyte complex nanoparticles; VRP, verapamil.

demonstrated that P-gp-mediated MDR could be overcome by encapsulating anticancer drug vincristine and VRP in poly(lactic-co-glycolic) acid (PLGA) nanoparticles. ${ }^{42}$

\section{Cellular uptake study}

To study the uptake kinetics of different PENPs in MCF-7 and MCF-7/ADR cells, cells were treated with DOX solution, DOXPENPs, and DOX-VRP-PENPs at different times and concentrations, where DOX was used as a fluorescent probe for flow cytometry. The particle sizes and zeta potentials ofDOX-PENPs and DOX-VRP-PENPs, and EE\% of DOX were $206 \pm 3.12 \mathrm{~nm}$, $210.54 \pm 2.36 \mathrm{~nm},-22.66 \pm 1.23 \mathrm{mV},-20.18 \pm 2.14 \mathrm{mV}$, $98.84 \% \pm 2.34 \%$, and $99.27 \% \pm 1.21 \%$, respectively. EE\% of VRP in DOX-VRP-PENPs was $45.67 \% \pm 1.47 \%$. Furthermore, the DOX released from the PENPs was released in a controlled release manner similar to the release of MTO (data not shown). Figure 5C and D illustrates that there was an obvious concentration-dependent internalization of DOX solution, DOX-PENPs, and DOX-VRP-PENPs in MCF-7 and MCF-7/ADR cells up to $4 \mathrm{~h}$. In either MCF-7 or MCF-7/ ADR cells, the uptake of the DOX solution group was higher than that of the nanoparticle group when DOX concentration was $\leq 5 \mu \mathrm{g} / \mathrm{mL}$. Hydrophilic DOX could move along with water molecules into the cells through the passive transport, ${ }^{43}$ this was much faster than the active PENP uptake process. Fluorescent intensity of DOX-PENPs in MCF-7 cells at $20 \mu \mathrm{g} / \mathrm{mL}$ concentration and at $4 \mathrm{~h}$ was significantly enhanced as HA-based CD44 targeting could have promoted the endocytosis of nanoparticles by cells. ${ }^{44} \mathrm{MCF}-7 / \mathrm{ADR}$ cells' uptake of DOX solution was much lower than the MCF-7 cells, indicating obvious efflux of DOX from MCF-7/ADR cells. PENPs co-loaded with VRP could improve MCF-7/ ADR cell uptake of DOX significantly, which suggests that the VRP could inhibit the extracellular efflux mechanism of DOX-VRP-PENPs in MCF-7/ADR cells by P-gp. Drugresistant cells may have more P-gp, and the co-loaded PENPs showed better reversal effect.

In either MCF-7 or MCF-7/ADR cells (Figure 5E and F), the DOX solution reflected faster uptake than DOX-PENPs and DOX-VRP-PENPs in the first $2 \mathrm{~h}$. On the other hand, the uptake curves of DOX-PENPs and DOX-VRP-PENPs increased quickly after $2 \mathrm{~h}$. The total uptake concentration of DOX-VRP-PENPs at $8 \mathrm{~h}$ in MCF-7/ADR cells was significantly higher than that of DOX solution (1.55 times) and DOX-PENPs (1.42 times) owing to the presence of VRP to inhibit the efflux of DOX. ${ }^{45}$ The total uptake concentration of DOX-VRP-PENPs in MCF-7 cells at $8 \mathrm{~h}$ was slightly higher than that of the other two groups, which was consistent with uptake condition under different concentrations.

To further study the intracellular location of PENPs co-loaded with VRP, the MCF-7/ADR cells were visualized post incubation with DOX-VRP-PENPs for $4 \mathrm{~h}$ by CLSM. As depicted in Figure 5G, red fluorescence of DOX and blue fluorescence of Hoechst 33342 almost overlapped in MCF-7/ ADR cells' nuclei. This certainly showed that DOX-VRPPENPs successfully reached the nucleus in significant quantities after getting into the cells, to ensure the cytotoxic role of DOX. ${ }^{46,47}$ Overall, these results iterate that PENPs co-loaded with VRP have great potential for the delivery of cytotoxic drugs to overcome MDR in tumor treatments. 
A

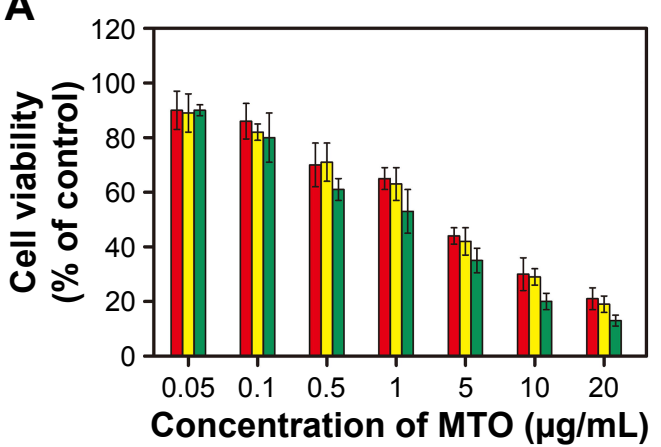

B

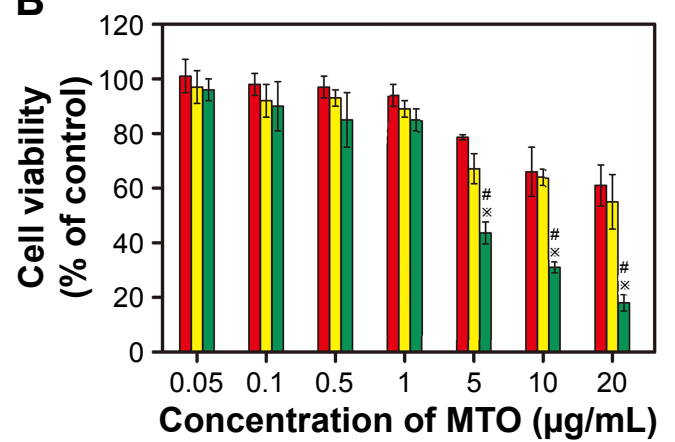

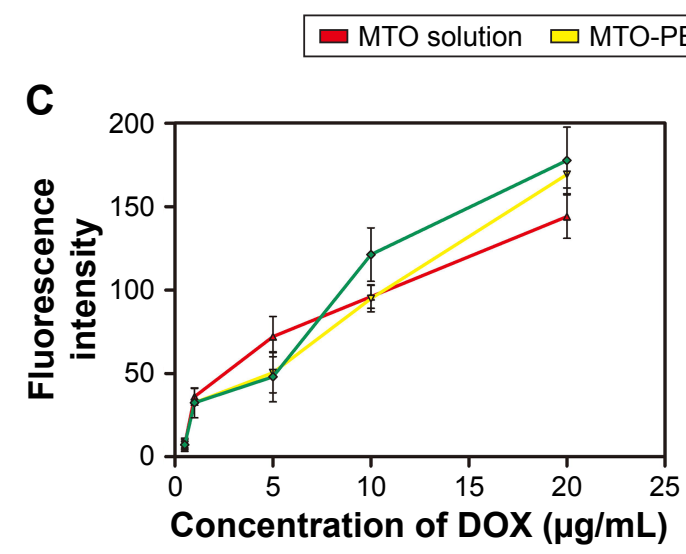

$\mathbf{E}$

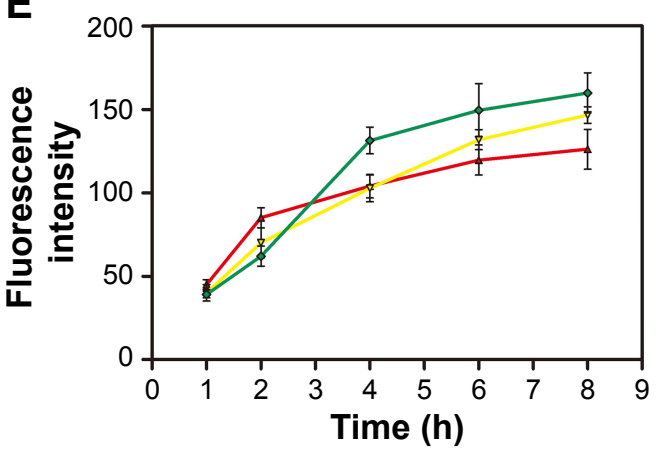

D

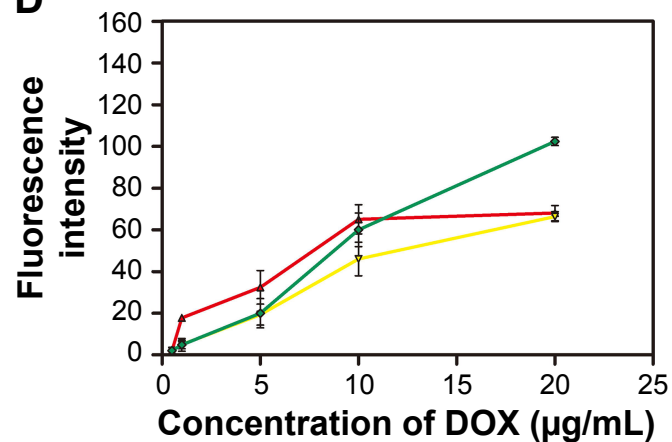

$\mathbf{F}$

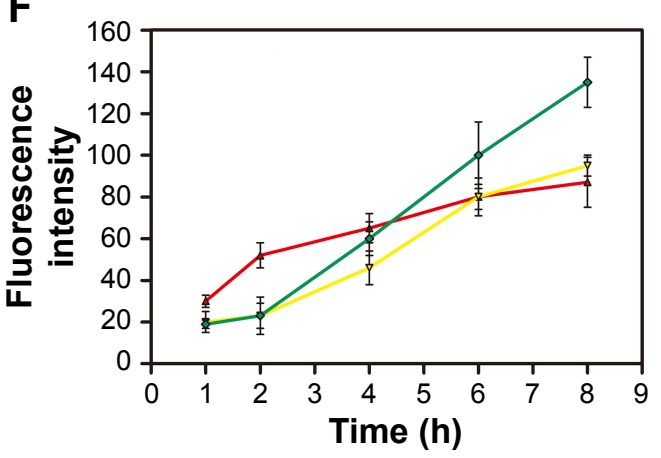

\section{G}

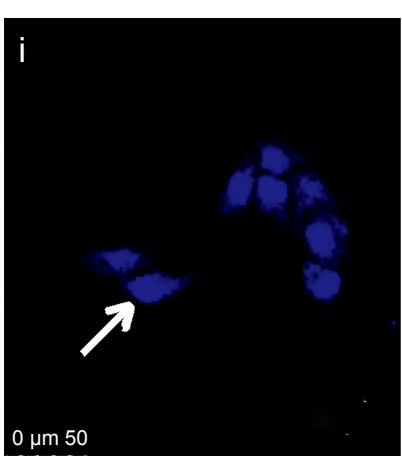

$\rightarrow$ DOX solution $\rightarrow$ DOX-PENPs $\leadsto$ DOX-VRP-PENPs
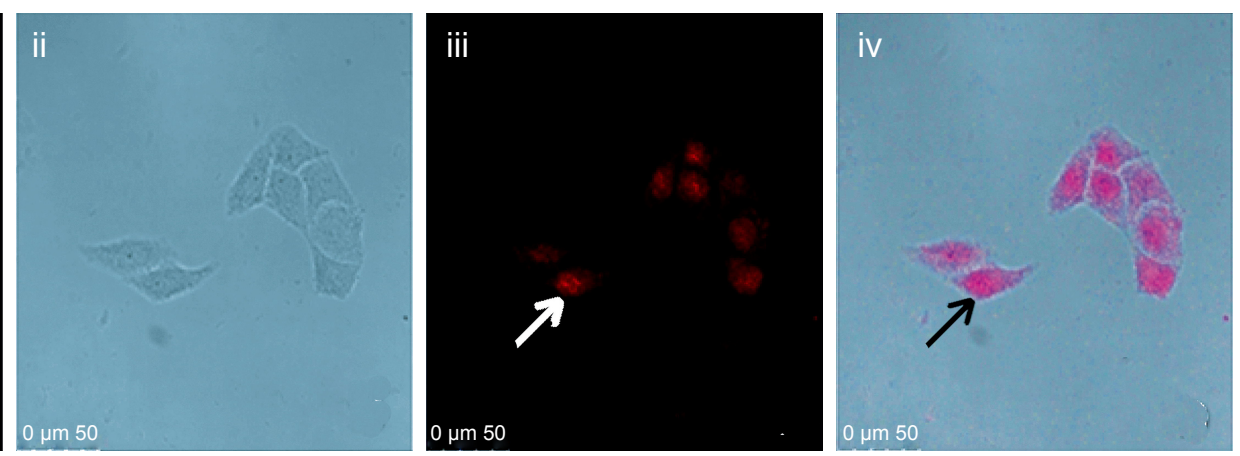

Figure 5 In vitro cells study.

Notes: MTT assay of MTO solution, MTO-PENPs, and MTO-VRP-PENPs in MCF-7 cells (A) and MCF-7/ADR cells (B) for 24 h. Uptake of various concentrations of DOX solution, DOX-PENPs, and DOX-VRP-PENPs by MCF-7 cells (C) and MCF-7/ADR cells (D) at $37^{\circ} \mathrm{C}$ for 4 h. Uptake of DOX solution, DOX-PENPs, and DOX-VRP-PENPs by MCF-7 cells $(\mathbf{E})$ and MCF-7/ADR cells $(\mathbf{F})$ at different time points, at $37^{\circ} \mathrm{C}$ and, $10 \mu \mathrm{g} / \mathrm{mL}$ of DOX. CLSM images of MCF-7/ADR cells (G) incubated with DOX-VRP-PENPs for $4 \mathrm{~h}(10 \mu \mathrm{g} / \mathrm{mL}$ DOX): i, cell nuclei dyed by Hoechst 33342; ii, cell outline in bright field; iii, DOX distribution in MCF-7/ADR cells; iv, overlay graph of i, ii, and iii ( $\mathrm{n}=3$ ) $\left({ }^{\circledR} P<0.05\right.$ versus MTO solution; ${ }^{\sharp P}<0.05$ versus MTO-PENPs). MTO-PENPs, MTO-loaded PENPs; MTO-VRP-PENPs, PENPs co-loaded with MTO and VRP.

Abbreviations: CLSM, confocal laser scanning microscopy; DOX, doxorubicin; MTO, mitoxantrone; MTT, 3-(4,5-dimethylthiazol-2-yl)-2,5-diphenyltetrazolium bromide; PENPs, polyelectrolyte complex nanoparticles; VRP, verapamil. 
Table 10 The cell RR (RR\%) of DOX solution, DOX-PENPs, and DOX-VRP-PENPs in MCF-7/ADR cells at different time intervals by flow cytometry $(\bar{X} \pm S D, n=3)$

\begin{tabular}{llll}
\hline Time (h) & DOX solution & DOX-PENPs & DOX-VRP-PENPs \\
\hline 0.5 & $54.43 \pm 4.64$ & $54.76 \pm 3.67$ & $76.41 \pm 3.87^{*, \#}$ \\
1 & $46.04 \pm 4.80$ & $47.43 \pm 7.10$ & $71.79 \pm 2.92^{*, \#}$ \\
2 & $42.82 \pm 3.40$ & $40.22 \pm 7.22$ & $62.44 \pm 8.75^{*, \#}$ \\
4 & $40.85 \pm 2.46$ & $32.93 \pm 4.34$ & $60.17 \pm 4.06^{*, \#}$ \\
\hline
\end{tabular}

Notes: $* P<0.05$, compared with DOX solution. ${ }^{*} P<0.05$, compared with DOXPENPs.

Abbreviations: DOX, doxorubicin; PENPs, polyelectrolyte complex nanoparticles; $R R$, retention rate; VRP, verapamil.

\section{Cell RR study}

As evident from Table 10, the RR of both the DOX solution and DOX-PENPs groups immediately dropped to about $54 \%$ just after $0.5 \mathrm{~h}$ post incubation with MCF-7/ADR cells. However, the retention capacity of DOX-VRP-PENPs in MCF-7/ADR cells was around $60 \%$ even at $4 \mathrm{~h}$ post incubation. These results showed obvious reversal of MDR effected by co-loaded nanoparticles. In addition, $\mathrm{IC}_{50}$ of free MTO, MTO-PENPs, and MTO-VRP-PENPs on MCF-7/ ADR cells was $49.15,38.33$, and $3.71 \mu \mathrm{g} / \mathrm{mL}$, respectively (Table 11). The enhanced cytotoxicity of MTO-PENPs was mainly attributed to the effect of PENPs which can be internalized into tumor cells via CD44. The reversal index of MTO-PENPs on MCF-7/ADR cells was improved as reversal index was 1.28 compared to free MTO. The reversal index of MTO-VRP-PENPs on MCF-7/ADR cells was markedly improved (13.25 times to free MTO, and 10.33 times to MTO-PENPs), suggesting that the co-loaded PENPs could effectively reverse MDR of tumor cells. The enhanced efficacy of MTO-VRP-PENPs on MCF-7/ADR cells might result from the synergistic effect of VRP and MTO. The presence of VRP in PENPs would have affected the efflux of MTO, thus increasing residence time of the cytotoxic drug and hence its activity.

Table I I IC $I_{50}$ values and reversal index of free MTO, MTOPENPs, and MTO-VRP-PENPs in MCF-7/ADR cells

\begin{tabular}{llll}
\hline Time (h) & IC $_{50}(\mu \mathrm{g} / \mathrm{mL})$ & \multicolumn{2}{l}{ Reversal index } \\
\hline Free MTO & $49.15 \pm 0.28$ & - & \\
MTO-PENPs & $38.33 \pm 0.38$ & $1.28^{*}$ & - \\
MTO-VRP-PENPs & $3.71 \pm 0.15$ & $13.25^{*}$ & $10.33^{\Delta}$ \\
\hline
\end{tabular}

Notes: *The ratio of $I C_{50}$ of free MTO to $I C_{50}$ of other MTO formulations. ${ }^{\Delta}$ The ratio of $I_{50}$ of MTO-PENPs to IC $\mathrm{IC}_{50}$ of MTO-VRP-PENPs. -, no detection; MTOPENPs, MTO-loaded PENPs; MTO-VRP-PENPs, PENPs co-loaded with MTO and VRP. Data presented as mean \pm standard deviation, $n=3$.

Abbreviations: MTO, mitoxantrone; PENPs, polyelectrolyte complex nanoparticles; VRP, verapamil.

\section{Conclusion}

In this study, we successfully co-encapsulated MTO and P-gp inhibitor VRP in PENPs based on HA and HCS. Various factors were observed to affect the size, zeta potential, and EE\% of MTO and VRP in the co-loaded PENPs. Optimized MTO-VRP-PENPs possessed a particle size and zeta potential of about $200 \mathrm{~nm}$ and $-23.98 \pm 3.03 \mathrm{mV}$, respectively. EE\% of MTO and VRP was $98.33 \% \pm 0.27 \%$ and $44.21 \% \pm 8.62 \%$, respectively. MTO and VRP were encapsulated in the PENPs in a molecular state. Importantly, MTO-VRP-PENPs showed improved cytotoxicity, cellular uptake, and significant reversal of drug resistance in MCF-7/ADR cells in contrast to the MTO-PENPs. Our results suggest that MTO-VRPPENPs could be a potential system to overcome tumor drug resistance.

\section{Acknowledgments}

This work has been supported by the National Natural Science Foundation of China (Program No 81503027) and College Students Innovation Project for the R\&D of Novel Drugs (Program No J1030830).

\section{Disclosure}

The authors report no conflicts of interest in this work.

\section{References}

1. Reszka R, Beck P, Fichtner I, Hentschel M, Richter J, Kreuter J. Body distribution of free, liposomal and nanoparticle-associated mitoxantrone in B16-melanoma-bearing mice. J Pharmacol Exp Ther. 1997;280(1): 232-237.

2. Imai Y, Tsukahara S, Asada S, Sugimoto Y. Phytoestrogens/flavonoids reverse breast cancer resistance protein/ABCG2-mediated multidrug resistance. Cancer Res. 2004;64(12):4346-4352.

3. Huang Y, Cole SP, Cai T, Cai YU. Applications of nanoparticle drug delivery systems for the reversal of multidrug resistance in cancer. Oncol Lett. 2016;12(1):11-15.

4. Amin ML. P-glycoprotein inhibition for optimal drug delivery. Drug Target Insights. 2013;7(7):27-34.

5. Tsuruo T, Iida H, Tsukagoshi $\mathrm{S}$, et al. Overcoming of vincristine resistance in leukemia in vivo and in vitro through enhanced cytotoxicity of vincristine and vinblastine by verapamil. Cancer Res. 1981;41(5): 1967-1972.

6. Muller C, Goubin F, Ferrandis E, et al. Evidence for transcriptional control of human mdr1 gene expression by verapamil in multidrug-resistant leukemic cells. Mol Pharmacol. 1995;47(1):51-56.

7. Tsubaki M, Komai M, Itoh $\mathrm{T}$, et al. By inhibiting src, verapamil and dasatinib overcome multidrug resistance via increased expression of bim and decreased expressions of mdr1 and survivin in human multidrugresistant myeloma cells. Leuk Res. 2014;38(1):121-130.

8. Nikolaeva O, Budtova $\mathrm{T}$, Alexeev V, et al. Interpolymer complexation between polyacrylic acid and cellulose ethers: formation and properties. J Polym Sci Polym Phys. 2000;38(10):1323-1330.

9. Eliaz RE, Szoka FC. Liposome-encapsulated doxorubicin targeted to CD44: a strategy to kill CD44-overexpressing tumor cells. Cancer Res. 2001;61(6):2592-2601. 
10. Yoon HY, Koo H, Choi KY, et al. Tumor-targeting hyaluronic acid nanoparticles for photodynamic imaging and therapy. Biomaterials. 2012;33(15):3980-3989.

11. Lee H, Mok H, Lee S, Oh YK, Park TG. Target-specific intracellular delivery of siRNA using degradable hyaluronic acid nanogels. J Control Release. 2007;119(2):245-252.

12. Choi KY, Chung H, Min KH, et al. Self-assembled hyaluronic acid nanoparticles for active tumor targeting. Biomaterials. 2010;31(1): 106-114.

13. Yang L, Gao S, Asghar S, et al. Hyaluronic acid/chitosan nanoparticles for delivery of curcuminoid and its in vitro evaluation in glioma cells. Int J Biol Macromol. 2015;72:1391-1401.

14. Zhao Y, Zhou Y, Wang D, et al. pH-responsive polymeric micelles based on poly(2-ethyl-2-oxazoline)-poly(d,1-lactide) for tumor-targeting and controlled delivery of doxorubicin and p-glycoprotein inhibitor. Acta Biomater. 2015; 17:182-192.

15. Meng L, Xia X, Yang Y, et al. Co-encapsulation of paclitaxel and baicalein in nanoemulsions to overcome multidrug resistance via oxidative stress augmentation and P-glycoprotein inhibition. Int J Pharm 2016;513(1-2):8-16.

16. Chi Y, Yin X, Sun K, et al. Redox-sensitive and hyaluronic acid functionalized liposomes for cytoplasmic drug delivery to osteosarcoma in animal models. J Control Release. 2017;261:113-125.

17. Kratz F, Warnecke A. Finding the optimal balance: challenges of improving conventional cancer chemotherapy using suitable combinations with nano-sized drug delivery systems. J Control Release. 2012;164(2):221-235.

18. Wan L, Jiao J, Cui Y, et al. Hyaluronic acid modified mesoporous carbon nanoparticles for targeted drug delivery to cd44-overexpressing cancer cells. Nanotechnology. 2016;27(13):135102.

19. Tang J, Zhang L, Gao H, et al. Co-delivery of doxorubicin and p-gp inhibitor by a reduction-sensitive liposome to overcome multidrug resistance, enhance anti-tumor efficiency and reduce toxicity. Drug Deliv 2014;23(4):1130-1143.

20. Chen B, Wu C, Zhuo RX, et al. A self-assembled albumin based multiple drug delivery nanosystem to overcome multidrug resistance. RSC Adv. 2015;5(9):6807-6814.

21. Čalija B, Savić S, Krajišnik D, et al. pH-sensitive polyelectrolyte films derived from submicron chitosan/eudragit ${ }^{\mathbb{1}} 100-55$ complexes: physicochemical characterization and in vitro drug release. J Appl Polym Sci. 2015;132(39):42583.

22. Liu Z, Wu XY, Bendayan R. In vitro investigation of ionic polysaccharide microspheres for simultaneous delivery of chemosensitizer and antineoplastic agent to multidrug-resistant cells. J Pharm Sci. 1999; 88(4):412-418.

23. He X, Wang J, Dou J, et al. Antitumor efficacy induced by a tumor cell vaccine treated with mitoxantrone alone or in combination with reserpine and verapamil in mice. Exp Ther Med. 2011;2(5):911-916.

24. Chen JW, Qiu WL, He RG. Verapamil enhancement of antitumor effect of mitoxantrone on ACC-2 cell line in vitro and in vivo. Zhonghua Kou Qiang Yi Xue Za Zhi. 1994;29(5):262-265.

25. Tsuchida E, Abe K, Honma M. Aggregation of polyion complexes between synthetic polyelectrolytes. Macromolecules. 1976;9(1) $112-117$.

26. Jewell CM, Zhang J, Fredin NJ, Wolff MR, Hacker TA, Lynn DM. Release of plasmid DNA from intravascular stents coated with ultrathin multilayered polyelectrolyte films. Biomacromolecules. 2006;7(9): 2483-2491.

27. Halder A, Maiti S, Sa B. Entrapment efficiency and release characteristics of polyethyleneimine-treated or -untreated calcium alginate beads loaded with propranolol-resin complex. Int J Pharm. 2005; 302(1-2):84-94.
28. Karibyants N, Dautzenberg H. Preferential binding with regard to chain length and chemical structure in the reactions of formation of quasisoluble polyelectrolyte complexes. Langmuir. 1998;14(16):4427-4434.

29. Schatz C, Lucas JM, Viton C, Domard A, Pichot C, Delair T. Formation and properties of positively charged colloids based on polyelectrolyte complexes of biopolymers. Langmuir. 2004;20(18):7766-7778.

30. Buchhammer HM, Mandy M, Marina O. Formation of mono-sized polyelectrolyte complex dispersions: effects of polymer structure, concentration and mixing conditions. Colloids Surf A. 2003;218(1):151-159.

31. Peng Y, Sun HY, Wang ZC, Xu XD, Song JC, Gong ZJ. Fabrication of alginate/calcium carbonate hybrid microparticles for synergistic drug delivery. Chemotherapy. 2016;61(1):32-40.

32. Mekhloufi G, Sanchez C, Renard D, Guillemin S, Hardy J. pH-induced structural transitions during complexation and coacervation of betalactoglobulin and acacia gum. Langmuir. 2005;21(1):386-394.

33. Ghosh S, Kobal I, Zanette D, et al. Conformational contraction and hydrolysis of hyaluronate in sodium hydroxide solutions. Macromolecules. 1993;26(17):4685-4693.

34. Shu S, Zhang X, Teng D. Polyelectrolyte nanoparticles based on water-soluble chitosan-poly (1-aspartic acid)-polyethylene glycol for controlled protein release. Carbohydr Res. 2009;344(10):1197-1204.

35. Hu T, Cao H, Yang C, et al. LHD modified mechanism-based liposome co-encapsulation of mitoxantrone and prednisolone using novel lipid bilayer fusion for tissue-specific co-localization and synergistic antitumor effects. ACS Appl Mater Inter. 2016;8(10):6586-6601.

36. Leonardi D, Salomon CJ. Unexpected performance of physical mixtures over solid dispersions on the dissolution behavior of benznidazole from tablets. J Pharm Sci. 2013;102(3):1016-1023.

37. Qin M, Lee YE, Ray A, Kopelman R. Overcoming cancer multidrug resistance by codelivery of doxorubicin and verapamil with hydrogel nanoparticles. Macromol Biosci. 2014;14(8):1106-1115.

38. Krishna R, Mayer LD. Multidrug resistance (MDR) in cancer: mechanisms, reversal using modulators of MDR and the role of MDR modulators in influencing the pharmacokinetics of anticancer drugs. Eur J Pharm Sci. 2000;11(4):265-283.

39. Gottesman MM, Pastan I. Biochemistry of multidrug resistance mediated by the multidrug transporter. Annu Rev Biochem. 1993;62(1): 385-427.

40. Fardel O, Lecureur V, Guillouzo A. The p-glycoprotein multidrug transporter. Gen Pharmacol. 1996;27(8):1283-1291.

41. Stavrovskaya AA. Cellular mechanisms of multidrug resistance of tumor cells. Biochemistry (Mosc). 2000;65(1):95-106.

42. Song XR, Cai Z, Zheng Y, et al. Reversion of multidrug resistance by co-encapsulation of vincristine and verapamil in PLGA nanoparticles. Eur J Pharm Sci. 2009;37(3-4):300-305.

43. Niu J, Huang A, Xiao Y, et al. Octreotide-mediated tumor cell uptake and intracellular ph-responsive drug delivery of the self-assembly supramolecular nanocarrier. J Drug Target. 2013;21(5):415-426.

44. Su Z, Chen M, Xiao Y, et al. Ros-triggered and regenerating anticancer nanosystem: an effective strategy to subdue tumor's multidrug resistance. J Control Release. 2014;196(11):370-383.

45. Wong HL, Bendayan R, Rauth AM, Wu XY. Development of solid lipid nanoparticles containing ionically complexed chemotherapeutic drugs and chemosensitizers. J Pharm Sci. 2004;93(8):1993-2008.

46. Febvay S, Marini DM, Belcher AM, Clapham DE. Targeted cytosolic delivery of cell-impermeable compounds by nanoparticlemediated, light-triggered endosome disruption. Nano Lett. 2010;10(6): 2211-2219.

47. Wu C, Gong MQ, Liu BY, Zhuo RX, Cheng SX. Co-delivery of multiple drug resistance inhibitors by polymer/inorganic hybrid nanoparticles to effectively reverse cancer drug resistance. Colloids Surf B Biointerfaces. 2017;149:250-259. 


\section{Publish your work in this journal}

The International Journal of Nanomedicine is an international, peerreviewed journal focusing on the application of nanotechnology in diagnostics, therapeutics, and drug delivery systems throughout the biomedical field. This journal is indexed on PubMed Central,

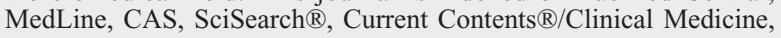

Journal Citation Reports/Science Edition, EMBase, Scopus and the Elsevier Bibliographic databases. The manuscript management system is completely online and includes a very quick and fair peer-review system, which is all easy to use. Visit http://www.dovepress.com/ testimonials.php to read real quotes from published authors.

Submit your manuscript here: http://www.dovepress.com/international-journal-of-nanomedicine-journal 